FACTA UNIVERSITATIS

Series: Economics and Organization Vol. 14, N $\mathrm{N}^{\mathrm{o}}$ 3, 2017, pp. 203 - 216

https://doi.org/10.22190/FUEO1703203A

Original Scientific Paper

\title{
DESCRIPTIVE ANALYSIS OF COMPETITION AND THE ADOPTION OF GAME THEORY IN BUSINESS GAME AMONG SMALL SCALE CAFETERIAS IN NIGERIA
}

\author{
UDC 005.311.7:725.712(669)
}

\section{Danlami Joseph Aduku, Juwon Johnson Orugun, Akeem Tunde Nafiu}

Department of Business Administration, Kogi State University, Ayigba, Nigeria

\begin{abstract}
This study focused on the competitive situation and business game among small scale cafeterias in Nigeria. Thus, the study investigated factors influencing the competitive situation among small scale cafeteria businesses in Nigeria, and the adoption of game theory in the business game and its effect on the overall performance of small scale cafeterias in Nigeria. The study was conducted on the selected cafeteria businesses from ten areas in Ogun State, Nigeria. This study analyzed the data collected in table with descriptive method and applied Chi-square and ANOVA statistical method. Findings show that price, service quality and customer's value influence the competitive situation among small scale cafeterias, and that the adoption of game theory in business game has an effect on the overall performance of small scale cafeterias in Nigeria. Though, the empirical result proves the effect to be insignificant. The study concluded that factors (such as price, service quality and customer's value) account for the outlook of competitive situation among small scale cafeterias in Nigeria, and that cafeteria owners can grow competitive advantage by applying the assumption of game theory. This study therefore recommends that cafeteria owner-managers should pay close attention to prices; service quality and customer's value to enable them to enhance a viable competitive position in the business game.
\end{abstract}

Key words: Game theory, Competitive situation, Players, Payoff, Small Scale Cafeteria

JEL Classification: M19, D21, C70

Received February 26, 2017 / Revised March 18, 2017 / Revised May 17, 2017 / Accepted June 20, 2017 Corresponding author: Akeem Tunde Nafiu

Kogi State University, Department of Business Administration, Ayigba, Nigeria

E-mail: tundenafiu01@gmail.com 


\section{INTRODUCTION}

In the contemporary business world of today, competition is observed to be increasingly tough with a concomitant effect on business firms irrespective of sizes. Competition is systematically avoided by many small business owners in Nigeria based on the perception of threat, with little or no attention on opportunities resulting from rivalry. However, Wikipedia (2014) viewed competition as the rivalry among sellers trying to achieve such goals as increasing profits, market share, and sales volume by varying the elements of the marketing mix: price, product, distribution, and promotion. It is evident that competition also has potential positive payoff (which are many business firms' desires) such as increasing profits, market share and sales volume. Jhingan (2006) added that true competition consists of the life of constant struggle and rival against rival in pursuit of this payoff. Factually, this means that business competition is not just fierce, but opportunity-filled, development oriented and beneficial to players. One obvious fact about competition is that it involves a game that reveals a firm's strength and weaknesses; poses threats and exposes opportunities.

In the past when business issues were addressed using the old-rule-of-thumb in Nigeria, competition was viewed by business owners as an act of enmity. This $21^{\text {st }}$ century marks a period of change when few cafeteria owners in Nigeria engaged themselves in a rethink against the conventional application of spiritual forces in competition. They saw the need for cooperation and competition rather than the existing mode of spiritual warfare in the business environment. This implies that cafeteria businesses in Nigeria are obviously in the game of conflict and cooperation. This is in line with the basic division of games by Backović, Popović and Stamenković (2016) in accordance with game theory as separation on both cooperative and non-cooperative games. Firescu (2012) quoting Franklin D. Roosevelt expressed that 'competition has been shown to be useful up to a certain point and no further, but cooperation, which is the thing we must strive for today, begins where competition leaves off.' However, the assumption of game theory provides an insight into the problem of how to survive under a tough competitive situation posed by the rational and conservative behaviour of cafeteria owners in Nigeria. Backović et al. (2016) is of the position that a rational individual aspires to the best possible outcome (maximizing utility) in accordance with pre-defined rules.

In times of uncertainty, according to Lindstädt and Müller (2009), the assumptions are that game theory is highly critical to success, for it offers perspectives on how players might act under various circumstances, as well as other kinds of valuable information for making decisions. Therefore, game theory is considered as a guide that gives a format on how to compete effectively in the business game without losing everything.

The main objective of this study is to examine the competitive situation and business game among small scale cafeterias in Nigeria. The specific objectives of the study are:

i. To investigate factors influencing the competitive situation among small scale cafeteria businesses in Nigeria; and

ii. To investigate the effect of the adoption of game theory on the overall performance of small scale cafeterias in the business game in Nigeria. 


\section{REVIEW OF RELEVANT LITERATURE}

\subsection{Concept of business game}

Every business environment possesses the attributes of the real business game (competition). Thus, all business firms existing in this environment must engage in a strategic task not only to cope with the game, but to possess the necessary payoff. For a situation to be considered a game there must be at least two rational players who take into account one another's actions when formulating their own strategies (quickmba.com). This makes the business game increasingly fierce among players; as each player adopts tiger-like strategy to either outwit others or to survive the turbulence. The target among players is one payoff which is favourable and achievable by adopting all available techniques and strategies.

Figure 1 below shows that cafeteria business owners pursue the same goal, and undertake virtually the same course of actions to get this goal achieved. This informs that no cafeteria will attain maturity without constant struggle as a result of conflicting interests. Bergen (1962) posited that the theory of games is to analyze situations of conflicting interests. Bergen also expressed that in some cases the theory will enable us to find a solution without resorting to arbitrary rules. The understanding of the nature of the business game gives elegant knowledge that is crucial to effective competitiveness and comparative advantage of one cafeteria over other competitors in the same business environment. This will prevent the business from being bitten hard or extinguished by the so-called industrial tigers.

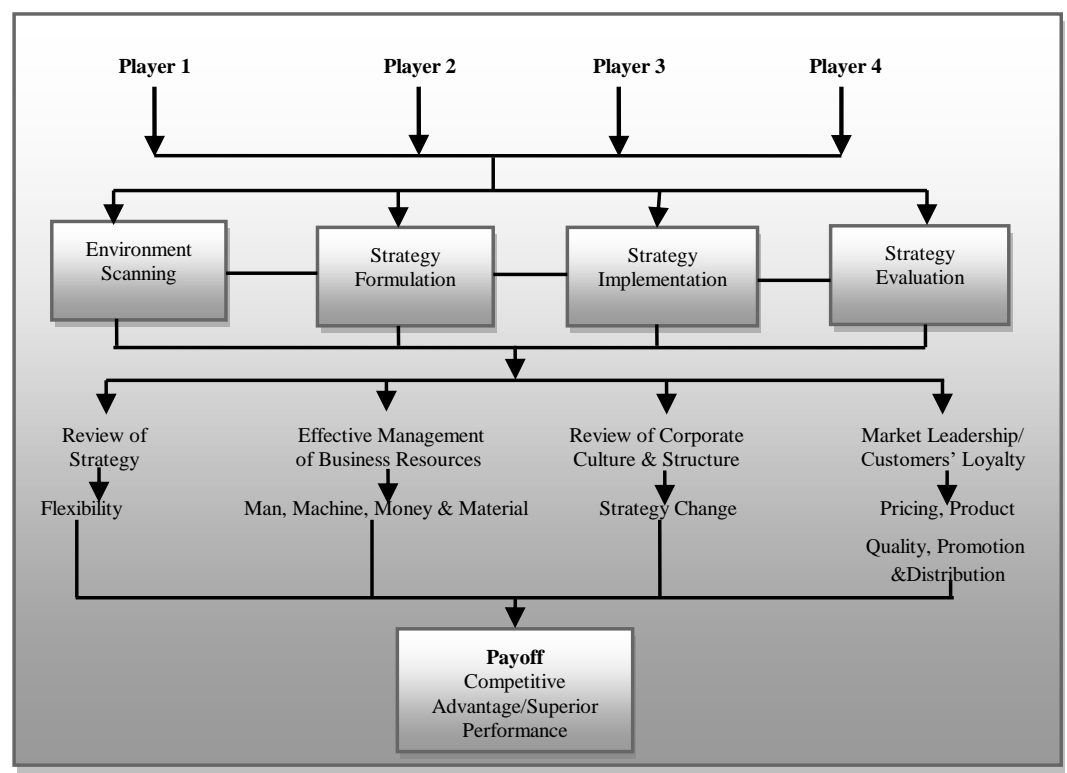

Fig. 1 The nature of a business game

In a game situation, each player spends time on the draw board to map out an edge-giving strategy against the opponents. Thus, it becomes imperative for these players to engage in the strategic management process as depicted in figure one. Consequently, these players will inevitably engage in a number of activities. Some of which are: 
i. Reviewing strategy (to enhance its flexibility),

ii. Managing resources effectively (such as man, machine, money and material),

iii. Reviewing corporate culture and structure (in alignment with strategy changes),

iv. Re-engineering the operation process (to enhance effective pricing strategy, product quality, promotion and distribution).

The rationale behind these activities is that each of the players is aware of the payoff at the sharp end of the business game. A player has to win to possess a positive payoff and the other must lose with a negative payoff.

\subsection{Categories of games}

This paper divides games into two categories:

i. Games that involve the application of strategy (Game of Strategy); which requires a high level of distinctive prowess, roadmap and strength of a player to compete effectively.

ii. Games that involve luck (Game of Luck); which requires the awareness of uncontrollable outcome. Playing this game involves the application of one's whole mind and not a skill.

Apart from the categories of games highlighted above and that of Backović et al. (2016), Crossman (n.d) also identified different kinds of games that are studied using game theory as follows:

i. Zero-sum game: Where the interest of the players are in direct conflict with one another. The winning player gets +1 (positive payoff) and the losing player gets -1 (negative payoff). Therefore, $+1-1=0$.

ii. Non-zero sum game: Where there is cooperation between the players and their interest are not conflicting directly in such a way that each player benefits from the game.

iii. Simultaneous move games: This involves putting the opponent in one's shoes. That is, believing that the opponent is doing exactly the same thing one is doing (Performing similar actions).

iv. Sequential move games: This involves following a sequential line of actions to compete effectively. Here, players select course of actions in orderly manner.

v. One-shot game: Crossman expressed that the players are likely not to know much about each other and gave an example, such as tipping a waiter on your vacation.

vi. Repeated games: Here, the same players have to compete repeatedly with one another.

\subsection{Game theory and its relevance to business game}

According to Nik and Nik (2008), the game theory has developed its application mainly in mathematics since its inception in 1944 by John von Neumann and Oskar Morgenstern. In a step further, Goluch (2012) elaborated that game theory is a study with the main purpose of finding an answer to the question: how to react in both conflict and cooperation situations, as well as combined ones. It is on this note that Backović et al. (2016) may have considered the basic division of game theory on cooperative games and non-cooperative games.

In game theory, a 'game' is a complete specification of the strategies each 'player' has, the order in which players choose strategies, the information players have, and how 
players value possible outcomes ('utilities') that result from strategy choices (Camerer, 2003). Game theory assumes that one has opponents, who are adjusting their strategies according to what they believe everybody else is doing (QuickMBA.com). Backović et al. (2016) also closely observed and posited that it is strategy oriented, and that it explores the expected outcomes, or how the outcomes are reached among actions undertaken by the players. In addition, Crossman (n.d.) stated clearly that the assumptions of game theorists are that:

i. The payoffs are known and fixed

ii. All players behave rationally

iii. The rules of the game are common knowledge.

It is no doubt that Game theory is a solution tool for the problem of competitive situation. This fact is also supported by the relevance of game theory compiled from Pinkasovitch (2014) as shown below:

i. That from optimal marketing campaign strategies, ideal auction tactics and voting styles, game theory provides a hypothetical framework with material implications.

ii. That Game theory provides the base for rational decision making.

This paper outlines other benefits that are accruable to the application of game theory as follows:

i. Game theory enables business owners or managers to be more proactive rather than being reactive in the business game, and also provides a reaction plan where necessary.

ii. It offers business owners an understanding of the business game and a befitting strategy for such situations.

iii. It is a solution tool for competitive situation considering the assumption that each player behaves rationally and conservatively.

iv. Through the adoption of Game theory, a player is able to maximize gain and minimize loss.

\subsection{Factors influencing competitive situation among small scale cafeterias in Nigeria}

A business firm as an entity has a long life cycle, separate from that of human's life expectancy. It is not anticipated to cease in its operation except in a situation where there is necessity for its termination. Igben (2007) rightly observed that a business is a going concern if it is capable of earning a reasonable net income (positive payoff) and there is no intention or threat from any source to curtail significantly its line of business in the foreseeable future.

Some cafeterias in Nigeria have noticeably faced consequential entropy; while some others are at the verge of collapse. It is the consequence of the fierce business game that is ignorantly given little concern. The competitive situation must exist in the market. A competitive situation exists when two or more cafeteria owners are aware independently of a certain goal which may be expressed in specific terms; and they rival against one another to achieve it. It is observed that many factors (price variation of similar customer's order among cafeterias, distinguished customers' value, quality of service delivery and strategic location of business) are attributable to the competitive situation of cafeterias in the business game in Nigeria. Though, Porter (1985) argued that five forces determine the intensity of the business game. These forces are captured in Figure 2 below: 


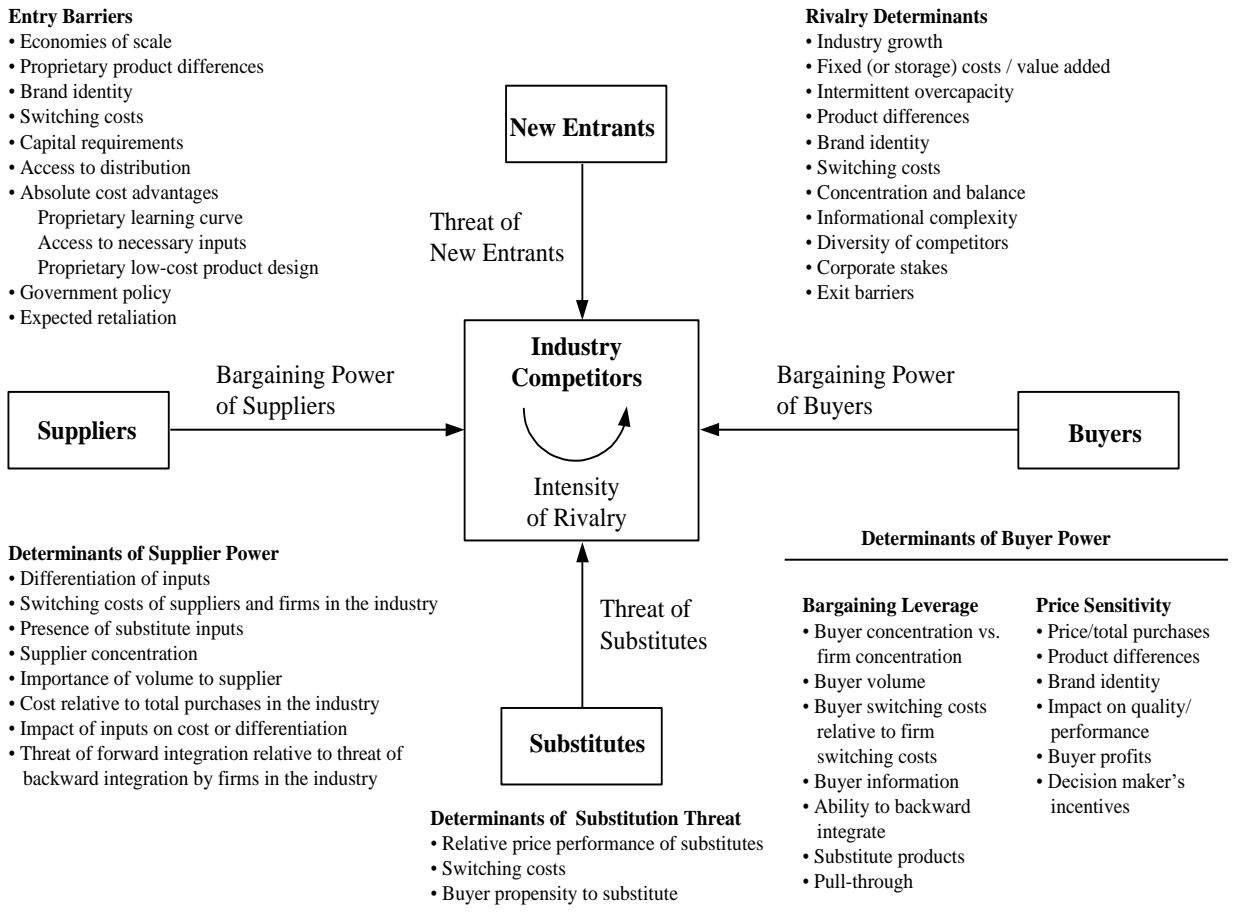

Fig. 2 Porter's five forces

Source: Porter, M. (1985). Competitive Advantage, New York: The Free Press.

Porter's five forces may not perfectly match with the survey intent of this study, due to the nature of the target population and the scope of the study.

Firstly, variation in prices of similar customers' orders is incredibly observed as determinants of the competitive situation among cafeterias in Nigeria. It is believed that no single player has total control over prices in the market of many competitors. The observed rationale behind variation in prices of similar orders is that some cafeteria owners try to build new competitive advantages in order to get others off the track. They might have engaged in pricing strategy to outwit others in the business game.

Secondly, the quest for value addition and good customer experience has become topical in the scheme of things. Customer's value is a subject of competition that is eminent in every business game. According to Zeithaml (1988), the term may mean low prices, receiving what is desired, receiving quality for what is paid, or receiving something in return for what is given. Entrepreneurial firms focus their scarce resources on the dimensions of value (e.g., cost, use value, emotional value, social value) (Smith and Colgate, 2007) that matter to customers the most and market their capabilities in terms that their customers can associate with and are known to value. Customers want benefit from the payment on the order they make; and they make preference of the cafeterias that can provide them with this. Delivering value to customers is a central aspect of cafeteria business that owners must ensure. This is equally the reason Shanker (2012) asserted that delivering customer value is not a one-off event, and firms must continuously strive to better understand and anticipate what their customers will value and then 
keep delivering it. To develop compelling customer's value propositions according to Shanker (2012), business owners need to keep in mind the following:

i. There are two stages at which customers assess value; before and after they purchase a product or service.

ii. Value is perceived at various levels; therefore, value needs to be delivered at various levels.

iii. Understanding what customer's value is; the first step in delivering customer value.

Thirdly, location is the strategy of geographical situation of a business firm in any business game. It would be agreed that location of the business is a strategic choice that must be made from varying alternatives. This strategic choice of location is costly, but has a long-run implication on the performance and survival of the business. It may be right to say that many cafeterias would have witnessed entropy in Nigeria within five years of start-up as a result of making the wrong decision about business location. Gerdeman (2012) posited that the strategic value of business location depends on three things. He quoted Juan Alcácer saying these things are:

i. The strength of available resources, such as nearby supporting industries;

ii. The company's ability to seek and retrieve knowledge in this setting; and

iii. Its capability to do something better than competitors.

Finally, relative standing (competitive advantage) has become an issue of concern to service based outputs the world over. Surpassing customer's expectation in service delivery and offerings takes the front burner. Every customer desires quality service delivery at any cafeteria. For instance; well packaged food, convenience and delicious food in a clean setting are attributes of quality service. Personalized service, good return policies, good relation-communication and ability to listen to customers' complaints also make up effective quality service delivery. These must have been considered by Bitner (1990) in his definition of service quality as the consumer's overall impression of the relative inferiority, superiority of the organization and its services. Amoako (2012) elaborated that, service quality is the key of survival to all servicing companies. In different view, Parasuraman, Zeithmal and Berry (1985) see services quality as a function of the differences between expectation and performance along the quality dimensions. However, the desired service expectation for customer's order usually involves employees' commitment and the competence of the cafeteria owner-managers. In essence, desired service expectations seem to be the same for service providers within industry categories or subcategories that are viewed as similar by customers (Amoako, 2012). In addition, the advent of smart phones poses a big threat to the survival of eateries because of increased awareness and exchange of valuable information via social media on improved service delivery and quality. The swing in consumers' taste as a result of preference for African delicacies has heightened the patronage of cafeterias in Nigeria.

This study observed that cafeteria owners' focus on the application of old-rule-ofthumb in lieu of result-driven strategies may not be efficient in addressing the competitive situation. A successful corporate strategy should modify these competitive forces in a way that improves the position of the organization (Porter, 1985). 


\section{RESEARCH METHODOLOGY}

The study used survey method. The study gathered its data and information through primary and secondary sources. The study was conducted on selected cafeteria businesses from ten areas in Ogun State, Nigeria. The population of the study was 124 (Sango - 14, Ifo - 27, Ijoko - 12, Owode - 11, Ijako - 8, Abeokuta - 21, Imeko Afon - 7, Badagri - 9, Ago iwoye - 10, Ilepa - 5). The Taro Yamane sampling method was used for sample size determination, and Bowler's proportional allocation formula was used to enhance fair allocation of samples to the study universe. The study adopted cluster sampling techniques, and further used simple random sampling to select the required sample size. This study analyzed the data collected in table with the descriptive method, and applied the Chi-square and ANOVA statistical method.

\section{Taro Yamane formula:}

$$
n=\frac{N}{1+N(e)^{2}}
$$

Where $n=$ sample size; $N=$ Population of the study (124); Error estimate at 5\% (0.05);

$$
1=\text { Constant. }
$$

$\frac{124}{1+124(0.05)^{2}}=\frac{124}{1+124(0.0025)}=\frac{124}{1+0.31}=\frac{124}{1.31}=94.656=95$

\section{Bowler's Proportional Allocation formula}

$$
n 1=\frac{n(n 1)}{N}
$$

Where $n=$ Overall sample size; $n 1=$ Population of metropolis; $N=$ The total population

$$
\begin{array}{lllll}
\mathrm{n}_{1}=\frac{95(14)}{124}=11 & \mathrm{n}_{2}=\frac{95(27)}{124}=21 & \mathrm{n}_{3}=\frac{95(12)}{124}=9 & \mathrm{n}_{4}=\frac{95(11)}{124}=8 & \mathrm{n}_{5}=\frac{95(8)}{124}=6 \\
\mathrm{n}_{6}=\frac{95(21)}{124}=16 & \mathrm{n}_{7}=\frac{95(7)}{124}=5 & \mathrm{n}_{8}=\frac{95(9)}{124}=7 & \mathrm{n}_{9}=\frac{95(10)}{124}=8 & \mathrm{n}_{10}=\frac{95(5)}{124}=4
\end{array}
$$

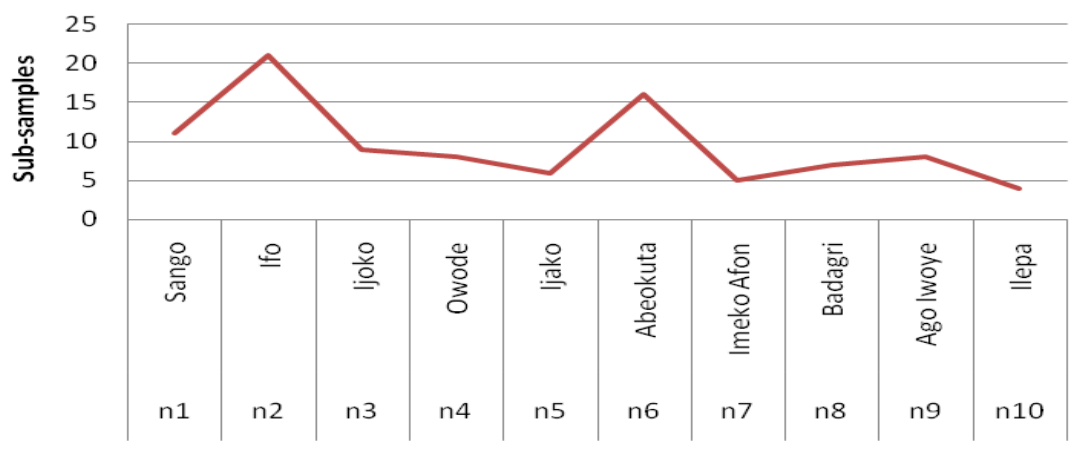

Fig. 3 Proportional allocation of sample size Source: Field Survey, 2016 


\section{The role of the researchers at the study area}

This study takes the period of almost two years. In the course of the study, the researchers lured the respondents into releasing facts by promising them confidentiality, and also a copy of the results of the survey. Having observed the erroneous interpretation given to competition by most cafeteria business owners, the researchers intensified effort towards enlightening the respondents concerning the subject matter. This was done by way of exposing them to the fact that games are going on among cafeteria business owners unknowingly and that there is a need for them to comprehend the efficacy of game theory and its applicability.

The researchers adopted the test and retest process to establish the reliability of the instrument. The researchers were then convinced that the instrument was reliable where the results were similar.

\section{DATA PRESENTATION AND ANALYSIS}

Table 1 Showing the demographic characteristics of respondents

\begin{tabular}{lcc}
\hline Demography & Responses & Percentage (\%) \\
\hline Gender & 79 & \\
Female & 16 & 83.2 \\
Male & 95 & 16.8 \\
\cline { 2 - 3 } Total & & \\
\hline Academic Qualification & 48 & 50.5 \\
$\quad$ Primary school Certificate & 32 & 33.7 \\
Secondary school/ND Certificate & 15 & 15.8 \\
HND/Bsc \& Above & 95 & 100 \\
Total & & 15.8 \\
Years of Business Existence & 15 & 28.4 \\
Up to 1 year & 27 & 30.5 \\
1-5 years & 29 & 25.3 \\
6-10 years & 24 & 100 \\
More than 10 years & 95 & \\
Total & 9516 \\
\hline
\end{tabular}

Source: Field Survey, 2016

Table 1 shows that 79 respondents $(83.2 \%)$ were female; and 16 respondents $(16.8 \%)$ were male. The implication of this is that female gender forms the major decision makers (players) and the majority in the ownership structure in this line of business when compared with their male counterpart.

The table depicts that 48 respondents $(50.5 \%)$ held Primary school certificates; 32 respondents $(33.7 \%)$ held Secondary school/ND certificates; and 15 respondents $(15.8 \%)$ held HND/BSc certificate and above. The implication of this is that $50.5 \%$ have little knowledge and skills regarding the tools or approaches to handling competitive issues in their business environment. Though, the $49.5 \%$ of respondents appear to have deep knowledge about the subject matter.

15 respondents $(15.8 \%)$ expressed that their businesses are up to 1 year old; 27 respondents (28.4\%) expressed that their businesses are within 1-5 years old; 29 respondents $(30.5 \%)$ expressed that their businesses are within 6-10 years old; 24 respondents (25.3\%) expressed that their businesses are more than 10 years old. The calculated average is 5.142, and this 
implies that the majority of the respondents have at least 5 years of business experience that is helpful to this present study.

Table 2 Describing factors influencing the competitive situation among small scale cafeterias in Nigeria

\begin{tabular}{|c|c|c|c|c|c|c|c|c|c|c|c|c|}
\hline \multirow[t]{2}{*}{ Factor } & \multirow[t]{2}{*}{ Response } & \multicolumn{10}{|c|}{ Frequency } & \multirow[t]{2}{*}{ Total } \\
\hline & & $\mathrm{n}_{1}$ & $\mathrm{n}_{2}$ & $\mathrm{n}_{3}$ & $\mathrm{n}_{4}$ & $\mathrm{n}_{5}$ & $\mathrm{n}_{6}$ & $\mathrm{n}_{7}$ & $\mathrm{n}_{8}$ & $\mathrm{n}_{9}$ & $\mathrm{n}_{10}$ & \\
\hline \multirow{6}{*}{$\begin{array}{l}\text { Price } \\
\text { Variation } \\
\text { of orders }\end{array}$} & GE & 5 & 8 & 2 & 5 & 1 & 8 & - & 6 & 5 & 1 & 41 \\
\hline & $\mathrm{AE}$ & 3 & 6 & 2 & 1 & 3 & 3 & - & 1 & - & 1 & 20 \\
\hline & LE & 3 & 7 & 5 & 2 & 2 & 5 & 5 & - & 3 & 2 & 34 \\
\hline & Total & 11 & 21 & 9 & 8 & 6 & 16 & 5 & 7 & 8 & 4 & 95 \\
\hline & Mean Score & 3.182 & 2.048 & 1.667 & 2.375 & 1.833 & 2.188 & 0.833 & 2.857 & 2.250 & 1.750 & 2.074 \\
\hline & Cut-off Point & 2.050 & 2.050 & 2.050 & 2.050 & 2.050 & 2.050 & 2.050 & 2.050 & 2.050 & 2.050 & 2.050 \\
\hline \multirow{6}{*}{$\begin{array}{l}\text { Value to } \\
\text { customer }\end{array}$} & GE & 7 & 18 & 4 & 8 & 4 & 11 & 1 & 3 & 2 & 2 & 60 \\
\hline & $\mathrm{AE}$ & 3 & 2 & 1 & - & - & 2 & 1 & 4 & 3 & 2 & 18 \\
\hline & LE & 1 & 1 & 4 & - & 2 & 3 & 3 & - & 3 & - & 17 \\
\hline & Total & 11 & 21 & 9 & 8 & 6 & 16 & 5 & 7 & 8 & 4 & 95 \\
\hline & Mean Score & 2.545 & 1.952 & 2.000 & 3.000 & 2.333 & 2.500 & 1.600 & 2.429 & 1.875 & 2.500 & 2.453 \\
\hline & Cut-off Point & 2.050 & 2.050 & 2.050 & 2.050 & 2.050 & 2.050 & 2.050 & 2.050 & 2.050 & 2.050 & 2.050 \\
\hline \multirow{6}{*}{$\begin{array}{l}\text { Quality of } \\
\text { service } \\
\text { delivery }\end{array}$} & GE & 2 & 7 & 3 & 6 & 4 & 7 & 3 & 3 & 7 & - & 42 \\
\hline & $\mathrm{AE}$ & 4 & 8 & 3 & 2 & - & 5 & 1 & $*$ & - & 4 & 27 \\
\hline & $\underline{\mathrm{LE}}$ & 5 & 6 & 3 & - & 2 & 4 & $*$ & $*$ & 1 & - & 21 \\
\hline & Total & 11 & 21 & 9 & 8 & 6 & 16 & 5 & 7 & 8 & 4 & 90 \\
\hline & Mean & 1.728 & 2.047 & 2.000 & 2.750 & 2.333 & 2.188 & 2.200 & 1.286 & 2.750 & 2.000 & 2.333 \\
\hline & Cut-off Point & 2.050 & 2.050 & 2.050 & 2.050 & 2.050 & 2.050 & 2.050 & 2.050 & 2.050 & 2.050 & 2.050 \\
\hline \multirow{6}{*}{$\begin{array}{l}\text { Availability } \\
\text { of facilities }\end{array}$} & GE & 3 & 6 & 2 & 1 & $*$ & 10 & $*$ & 3 & 7 & - & 32 \\
\hline & $\mathrm{AE}$ & 2 & 12 & 1 & 5 & 4 & 1 & 2 & 2 & 1 & 1 & 31 \\
\hline & LE & 6 & 3 & 6 & 2 & $*$ & 5 & 1 & 2 & - & 3 & 28 \\
\hline & Total & 11 & 21 & 9 & 8 & 6 & 16 & 5 & 7 & 8 & 4 & 91 \\
\hline & Mean & 1.727 & 2.143 & 1.556 & 1.875 & 1.333 & 2.313 & 1.000 & 2.143 & 2.875 & 1.250 & 2.044 \\
\hline & Cut-off Point & 2.050 & 2.050 & 2.050 & 2.050 & 2.050 & 2.050 & 2.050 & 2.050 & 2.050 & 2.050 & 2.050 \\
\hline
\end{tabular}

Based on the data analysis in Table 2 above, it is firstly observed that prices variation of customer's order in Sango (mean score= 3.182); Owode (mean score $=2.375$ ); Abeokuta (mean score $=2.188)$; Badagri (mean score $=2.857$ ); and Ago Iwoye (mean score $=2.250$ ) determine the level of competitive situation among small scale cafeteria businesses in these areas. In addition, competition (arising from price differentiation) among small scale cafeterias in Sango appears to be very strong given the highest mean score of 3.182. Generally, price variations of a particular customer's order among small scale cafeteria seem to have a weak influence on their competitive situation (given that the mean score $=2.074$ > cut-off point $=2.050)$. Price variations of identical customer's order among small scale cafeteria are accepted as a condition for the achievement of the desired payoff posed by business game in Ogun State. Thus, price variations of identical customer's order influences competitive situation among small scale cafeterias in Ogun State to a low extent.

Secondly, it could be observed that cafeteria owners in Sango (mean score $=2.545$ ); Owode $($ mean score $=3.000)$; Ijoko $($ mean score $=2.333)$; Abeokuta $($ mean score $=2.500)$; 
Badagri (mean score $=2.429$ ); and Ilepa (mean score $=2.500$ ) give out appreciable customer value. It appears that the competitive situation in Owode may be tough based on the great customer value given by the cafeteria owners in this area. In areas such as Ifo (mean score $=1.952)$; Ijoko $($ mean score $=2.000)$; Imeko Afon (mean score $=1.600)$; and Ago-Iwoye (mean score $=1.875)$, the customer value appears to be low. This may be as a result of lack of adequate knowledge about the significance of customers' patronage and their retention in these areas. On the general note, empirical verification proves that customers' value influence competitive situation in Ogun State to a moderate extent (given that the overall mean score $=2.453>$ the cut-off point $=2.050$ ). This implies that cafeteria owners pay genuine attention to customer's service, and ensure effective communication and relationship with their customers.

Thirdly, the table shows that cafeterias in Owode (mean score= 2.750); Ijako (mean score= 2.333); Abeokuta (mean score= 2.188); Imeko-Afon (mean score= 2.200); and Ago-Iwoye (mean score $=2.750$ ) embrace quality service delivery in their business environment. This implies that individual cafeteria owners know the benefit of providing distinguished service to customers in order to retain a reasonably large market share. Though, it is observed that cafeterias (in Sango, Ifo, Ijako and Badagri) have very low concern for service quality in their business environment. The result from Badagri (mean score= 1.286) may not be considered, given that colossal of data was missing. However, empirical investigation reveals that quality consideration of service delivery is a subject of competitive situation among cafeterias in Ogun State, Nigeria (given that the overall mean score $=2.233>$ the cut-off point $=2.050$ ). This implies that individual cafeteria owner's drive towards delivering high quality services will often strengthen competitive situation in the business environment. This aligns with the assertion of Crossman (n.d.) that all players behave rationally. Meanwhile, the game theory assumes that all players engage in similar task to obtain just one payoff. With this understanding, Porter (1985) emphasizes that a successful strategy needs to be formulated and implemented in a way that improves the position of the organization.

Finally, the table depicts that location of cafeterias in Ifo (mean score= 2.143); Abeokuta (mean score= 2.313); Badagri (mean score= 2.143); and Ago-Iwoye (mean score $=2.875)$ is a strategic point embraced by owners in these areas. It appears that cafeteria owners in other areas are indifferent about situating their businesses in strategic geographical areas. Empirical investigation reveals that locations of cafeterias in strategic places have little or no influence on the competitive situation in Ogun State (given that the overall mean score $=2.044<$ the cut-off point $=2.050)$.

Table 3 Showing adoption of game theory and its effect on overall performance of small scale cafeteria in Nigeria

\begin{tabular}{|c|c|c|c|c|c|c|c|c|c|c|c|c|}
\hline \multirow{2}{*}{$\begin{array}{l}\text { Observation/Expected } \\
\text { Frequency }\end{array}$} & \multicolumn{12}{|c|}{ Frequency } \\
\hline & $\mathrm{n} 1$ & $\mathrm{n} 2$ & $\mathrm{n} 3$ & $\mathrm{n} 4$ & $\mathrm{n} 5$ & n6 & $\mathrm{n} 7$ & $\mathrm{n} 8$ & n9 & $\mathrm{n} 10$ & Total & $\%$ \\
\hline Yes & 3 & 10 & 4 & 7 & 6 & 9 & 4 & 4 & 7 & 4 & 58 & 61.1 \\
\hline Exp. Freq & 6.72 & 12.82 & 5.49 & 4.88 & 3.66 & 9.77 & 3.05 & 4.27 & 4.88 & 2.44 & & \\
\hline No & 4 & 3 & 2 & - & - & 6 & 1 & 2 & - & - & 18 & 18.9 \\
\hline Exp. Freq & 2.08 & 3.98 & 1.71 & 1.52 & 1.14 & 3.03 & 0.95 & 1.33 & 1.52 & 0.76 & & \\
\hline Not Sure & 4 & 8 & 3 & 1 & - & 1 & - & 1 & 1 & - & 19 & 20.0 \\
\hline Exp. Freq & 2.20 & 4.20 & 1.80 & 1.60 & 1.20 & 3.20 & 1.00 & 1.40 & 1.60 & 0.80 & & \\
\hline Total & 11 & 21 & 9 & 8 & 6 & 16 & 5 & 7 & 8 & 4 & 95 & 100 \\
\hline
\end{tabular}




$$
X^{2}=\frac{\sum\left(F_{o}-F_{e}\right)^{2}}{F_{e}}=\mathbf{3 1 . 0 3 2}
$$

At $\alpha=0.05$ level of significance with 18 degrees of freedom, the critical value for $\mathrm{X}^{2}$ is 28.869 . Consequently, since the calculated $\mathrm{X}^{2}$ of 31.032 is greater than the critical value $\mathrm{X}^{2}$ of 28.869 (that is, $X^{2}>\mathrm{X}_{0.05}^{2}$ ). We therefore conclude that the adoption of game theory, in the business game, has an effect on the overall performance of small scale cafeterias in Nigeria. This implies that game theory is efficacious as a solution tool for addressing the business game. This finding augments the assertion of the study by Bergen (1962) that Game Theory has its purpose just to analyze such situations of conflicting interests. This is because the assumption of game theory will help owners to analyze the business game and determine an effective strategy to gain a desired pay-off.

Table 4 Showing differences in the adoption of game theory by small scale cafeterias

\begin{tabular}{lcccccccccccc}
\hline & $\mathrm{n} 1$ & $\mathrm{n} 2$ & $\mathrm{n} 3$ & $\mathrm{n} 4$ & $\mathrm{n} 5$ & $\mathrm{n} 6$ & $\mathrm{n} 7$ & $\mathrm{n} 8$ & $\mathrm{n} 9$ & $\mathrm{n} 10$ & F-Cal & F-Crit \\
\hline Mean & 2.091 & 1.905 & 1.889 & 1.250 & 1.000 & 1.500 & 1.200 & 1.571 & 1250 & 1.000 & 1.120 & 2.393 \\
SD & 0.831 & 0.944 & 0.927 & 0.707 & 0.001 & 0.632 & 0.447 & 0.787 & 0.707 & 0.001 & & \\
\hline \multicolumn{10}{c}{ SD - Standard Deviation; F-Crit $=F_{0.05}^{9.20}$}
\end{tabular}

Table 4 shows the description and variance analysis of the effect of the adoption of game theory on the overall performance of small scale cafeterias. Given the varying means, the result shows that mean of the effect of adoption by small scale among cafeterias in Sango (2.091) is very evident, as it is above the critical point. The standard deviation (0.831) shows that there is little divergence in the effect of the adoption of game theory by this small scale among cafeterias in Sango. This result implies that these small scale cafeterias now appreciate the assumption of game theory in their competitive business environment. It is also viewed from the table that though there are observed differences in the effect of the adoption of game theory among small scale cafeterias in other areas such as Ifo (mean-1.905, SD- 0.831), Ijoko (mean- 1.889, SD- 0.927), Owode (mean- 1.250, SD- 0.707), Ijako (mean- 1.000, SD- 0.001), Abeokuta (mean- 1.500, SD0.632), Imeko Afon (mean- 1.200, SD- 0.447), Badagri (mean- 1.571, SD- 0.787), Ago iwoye (mean- 1250, SD- 0.707), Ilepa (mean- 1.000, SD- 0.001); but it is not evident enough. The empirical result shows that there are no significant differences in the effect of the adoption of game theory by small scale cafeterias in the study areas. This may be as a result of little knowledge possessed regarding the adoption of game theory in these areas during the period of this present study.

\section{CONCLUSION}

Price and quality of service play a crucial role in the competitive situation among small scale cafeterias. Price interrelates with quality of service rendered by cafeteria owners. This means that all cafeteria owners are aware that high quality attracts high price, ceteris paribus. Thus, cafeteria owners pursue high quality-price or low quality-price approach to retain customers' patronage. In addition, creating customer's value is also an adopted approach by 
cafeteria owners to retain customers' patronage. Customer's value captures price affordability of orders and receiving quality for what is paid. The rational behind establishing customers' value is to enhance high sales and profitability. These factors account for the outlook of competitive situation among small scale cafeteria in Ogun State, Nigeria.

The adoption of game theory, in the business game, has an effect on the overall performance of small scale cafeterias in Nigeria. The bottom-line for evident effect of this adoption is the understanding of the game theory's assumptions. For cafeteria owners to grow competitive advantage, game theory is considered an essential tool. The assumption of game theory will guide owners in analyzing the business game and determining the effective strategy to apply to gain a desired pay-off.

Based on the findings above, the study recommends that:

i. Cafeteria owner-managers should analyze the price-benefit of orders to enable them to establish their competitive position in the business game. This will also enhance better knowledge of what price to set to win the business game.

ii. Cafeteria owner-managers should intensify the effort in making appropriate decisions regarding the location of their cafeterias in lieu of commitment of intensive resources.

iii. Cafeteria owners should ensure high quality service delivery and establishment of customer's value. Competitive advantage can be enhanced where customer's value and service quality are established.

iv. Cafeteria owners should adopt game theory to competitive situation in their business game. The assumption of game theory will guide owners in determining the effective strategy that is suitable for enhancing high performance of businesses in Ogun State, Nigeria.

\section{REFERENCES}

Amoako, P.M. (2012). The Role Employees Play in Service Delivery to Achieve Customer Satisfaction at the Imperial Perkin Fast Food Restaurant. MBA Thesis, Kwame Nkrumah University of Science and Technology.

Andersen, M.L. and Taylor, H.F. (2009). Sociology: The Essentials. In: A. Crossman (Ed.), Game Theory: An Overview. Retrieved from: sociology.about.com/od/Sociological-Theory/a/Game-Theory.htm. Accessed on: 29 March 2015.

Backović, M., Popović, Z. \& Stamenković, M. (2016). Reflexive Game Theory Approach to Mutual Insurance Problem. Montenegrin Journal of Economics, 12(3), 87-100.

Bergen, K.B. (1962). Application of Game Theory to Some Problems in Automobile Insurance, The Juan-lesPins Colloquium. 208-221.

Bitner, M.J. (1990). Evaluating service encounters: the effects of physical surrounding and employee response. In: Amoako, P.M. (Ed.). The Role Employees Play in Service Delivery to Achieve Customer Satisfaction at the Imperial Perkin Fast Food Restaurant. MBA Thesis, Kwame Nkrumah University of Science and Technology.

Camerer, C.F. (2003). Behavioural Studies of Strategic Thinking In Games, Trends in Cognitive Sciences. 7(5), 24-36.

Coomas, M. (2005). Fair Play or Loyalty and Coherence: A Source of Performance and Value Creation through Business Ethics. In: Firescu, I. (Ed.). Cooperation In Business - An Application Of Game Theory, Project, International Management Aarhus School of Business and Social Sciences.

Duffy, J. (2010). Lecture Notes: Elements of a Game. In A. Crossman (eds.), Game Theory: An Overview. Retrieved from: sociology.about.com/od/Sociological-Theory/a/Game-Theory.htm. Accessed on: 29 March 2015.

Firescu, I. (2012). Cooperation In Business - An Application Of Game Theory. Project, International Management Aarhus School of Business and Social Sciences. 
Gerdeman, D. (2012). Location, Location, Location: The Strategy of Place. Harvard Business School Working Knowledge: Business Research for Business Leaders. Retrieved from: http://hbswk.hbs.edu/item/locationlocation-location-the-strategy-of-place. Accessed on: 29 March 2015.

Goluch, T. (2012). The use of Game Theory in Small Business, Thesis, Gdansk University of Technology.

Igben, R.O. (2007), Financial Accounting Made Simple, $2^{\text {nd }}$ Edition, Lagos: ROI Publishers

Jhingan, M.L. (2006). Advance Economic Theory: Micro and Macro-economics, $12^{\text {th }}$ Edition, Delhi: Vrinda Publications.

Lindstädt, H \& Müller, J. (2009), Making Game Theory Work for Managers, Insights and Publications.

Nik, H. \& Nik, M. (2008). Strategies Of Game Theory In The Marketing Of Marine Catch For Small, Medium And Large Fishermen. IIFET: Vietnam Proceedings.

Parasuraman, A, Zeithaml, V.A. et al. (1988), SERVQUAL: A multiple item scale for measuring consumer perceptions of service quality. In: Amoako, P.M. (Ed.). The Role Employees Play in Service Delivery to Achieve Customer Satisfaction at the Imperial Perkin Fast Food Restaurant. MBA Thesis, Kwame Nkrumah University of Science and Technology.

Pinkasovitch, A. (2014), Why Is Game Theory Useful In Business, Investopedia. Retrieved from: www.investopedia.com/ask/answers/09/game-theory-business.asp. Accessed on: 29 March 2015.

Porter, M. (1980). Competitive Advantage: Creating and Sustaining Superior Performance. In: Recklies, D. (Ed.). Porter's Five Forces- Content, Application and Critique. Retrieved from: www.themanager.org. Accessed on: 29 March 2015.

Porter, M. (1985). Competitive Advantage, New York: The Free Press.

Porter, M. (1998). Competitive Strategy. New York: Free Press.

QuickMBA (n.d), Game Theory. Retrieved from: www.quickmba.com/econ/micro/gametheory/. Accessed on: 29 March 2015.

Shanker, A. (2012). What Is Customer Value and How Do You Deliver It? Technology Innovation Management Review, 2(2), 32-33.

Smith, J.B. \& Colgate, M. (2007). Customer Value Creation: A Practical Framework. Journal of Marketing Theory and Practice. 15(1), 7-23

Wikipedia (2014), Competition: Economics. Retrieved on 15 July, 2014 from: en.m.wikipedia.org/wiki/ Business_competition. Accessed on: 29 March 2015.

Zeithaml, V.A. (1988). Consumer Perceptions of Price, Quality, and Value: A Means-End Model and Synthesis of Evidence. Journal of Marketing, 52(3), 2-22.

\section{DESKRIPTIVNA ANALIZA KONKURENCIJE I USVAJANJA TEORIJE IGARA U POSLOVNOJ UTAKMICI MALIH KAFETERIJA U NIGERIJI}

Ova studija fokusirala se na konkurentsku situaciju i poslovnu utakmicu malih kafeterija u Nigeriji. Stoga su istraživani faktori koji utiču na konkurentsku situaciju malih kafeterija u Nigeriji i usvajanje teorije igara u poslovnoj utakmici, kao i njenog uticaja na ukupno poslovanje malih kafića u Nigeriji. Studija je sprovedena na odabranim kafeterijima iz deset oblasti u državi Ogun, $u$ Nigeriji. Ova studija analizirala je podatke prikupljene $u$ tabeli deskriptivnom metodom $i$ koristila Chi-kvadrat test i ANOVA statistički metod. Nalazi pokazuju da cena, kvalitet usluge $i$ vrednost za kupca utiču na konkurentsku situaciju u malim kafeterijama i da usvajanje teorije igara u poslovnoj utakmici utiče na ukupno poslovanje malih kafeterija u Nigeriji. Ipak, empirijski rezultat dokazuje da je uticaj beznačajan. Studija je zaključila da faktori (kao što su cena, kvalitet usluga $i$ vrednost za kupca) utiču na konkurentsku situaciju malih kafeterija u Nigeriji, $i$ da vlasnici kafeterija mogu povećati konkurentsku prednost primenom pretpostavki teorije igara. Zbog toga ova studija preporučuje da vlasnici-menadžeri kafeterija treba da obrate posebnu pažnju na cene, kvalitet usluge i vrednost za kupca što će - im omogućiti da poboljšaju održivu konkurentsku poziciju u poslovnoj utakmici.

Ključne reči: teorija igara, konkurentna situacija, igrači, isplata, male kafeterije 